\title{
Naturally occurring mutations to HCV protease inhibitors in treatment-naïve patients
}

\author{
Stefania Paolucci ${ }^{1}$, Loretta Fiorina ${ }^{1}$, Antonio Piralla', Roberto Gulminetti ${ }^{2}$, Stefano Novati ${ }^{2}$, Giorgio Barbarini ${ }^{3}$, \\ Paolo Sacchi ${ }^{3}$, Marta Gatti ${ }^{1}$, Luca Dossena ${ }^{1}$ and Fausto Baldanti ${ }^{{ }^{*}}$
}

\begin{abstract}
Background: Protease inhibitors (PIs) to treat hepatitis C (HCV) virus infection have been approved and others are under development.

Results: The aims of this study were to illustrate natural polymorphisms in the HCV protease and measure the frequency of $\mathrm{PI}$ resistance mutations in different HCV genotypes from Pl-naïve patients.

Direct sequencing of HCV NS3/4A protease was performed in $156 \mathrm{HCV}$ patients naïve to Pls who were infected with genotype 1a $(n=31), 1 b(n=39), 2(n=30), 3(n=33)$ and $4(n=23)$.

Amino acid (aa) substitutions associated with HCV PI resistance were found in 17/156 (10.8\%) sequences. Mutations V36L, T54S, V55A/l, and Q80K/L were observed in 29\% of patients with genotype 1a, and V55F, Q80L/N and M175L in $10 \%$ of patients with genotype $1 \mathrm{~b}$. The mutation V158M was found in $3 \%$ of patients with genotype 2, D168Q was present in 100\% of patients with genotype 3 and D168E was observed in 13\% of patients with genotype 4 . In addition, multiple aa polymorphisms not associated with PI resistance were detected in patients with genotypes 1a, $1 \mathrm{~b}$ and 4.
\end{abstract}

Conclusions: Although major PI resistance mutations were not detected, other resistance mutations conferring low level resistance to Pls together with a number of natural polymorphisms were observed in proteases of PI naïve HCV patients. A more extensive analysis is needed to better evaluate the impact of baseline resistance and compensatory mutations in the efficacy of HCV PI treatment.

Keywords: Hepatitis C virus, HCV baseline resistance, Protease inhibitors, HIV/HCV co-infection, Genetic diversity

\section{Background}

Hepatitis $\mathrm{C}$ virus (HCV) infects more than 170 million people worldwide [1]. Treatment with pegylated interferon- $\alpha$ and ribavirin is burdened by adverse reactions in a significant proportion of patients [2] and a sustained virological response is achieved in only $50 \%$ of patients infected with genotype 1 [3] and $80 \%$ of patients infected with genotype 2 [4]. Recently, inhibitors of HCV nonstructured serine -protease 3 (NS3/4A) have been approved (Telaprevir, Boceprevir), and others are under development (TMC435350, ITMN191, SCH900518, MK7009, BI-201335, MK5172, GS-9256, ABT 45, BMS791325 and $\mathrm{ACH}-1625)$ [5-9]. However, selection of drug-resistant $\mathrm{HCV}$ variants has already been reported

\footnotetext{
* Correspondence: f.baldanti@smatteo.pv.it

${ }^{1}$ Molecular Virology Unit, Virology and Microbiology Department, Fondazione IRCCS Policlinico San Matteo, Pavia 27100, Italy

Full list of author information is available at the end of the article
}

in protease inhibitor (PI)-treated individuals [7-14]. The degree of resistance appears to be related both to mutations at specific NS3 positions and to changes in amino acid (aa) residues $[5,7,15]$.

The high HCV replication rate and lack of a proofreading mechanism determine a natural variability, which promotes the rapid emergence of drug-resistant variants [15]. Natural aa changes in NS3 associated with reduced drug susceptibility have been observed in treatment naïve patients $[10,16,17]$. However, the clinical impact of baseline resistance and its influence on the ability of the virus to replicate in vivo remain unclear $[15,16]$. Recently, the sporadic transmission of naturally occurring NS3 resistance mutations was reported [16]. In addition, the impact of the frequency of baseline $\mathrm{HCV}$ PI resistance mutations in HIV/HCV co-infected patients with respect to $\mathrm{HCV}$ mono-infected patients is still debated [17-19]. The frequency of naturally

\section{Biomed Central}


occurring NS3 aa substitutions associated with PI resistance in treatment naïve HCV patients infected with genotypes 1, 2, 3 and 4 was investigated.

\section{Materials and methods}

HCV PI-naive patients referred to our hospital between 2010 and 2011 were included in the study. Patients were stratified according to HCV genotype and a comparable number of patients infected with HCV genotypes $1 \mathrm{a}, 1 \mathrm{~b}$, 2, 3 and 4 were sequentially enrolled in the study. Most (75\%) were treated with pegylated Interferon- $\alpha$ and Ribavirin, while none had ever been treated with a PI for hepatitis C. For NS3 sequencing, surplus serum samples were prospectively collected from each patient. HCV genotypes were defined using the Versant HCV Genotype 2.0 Assay LiPA (Siemens Healthcare Diagnostic Inc., Tarrytown, NY USA). The NS3 region was sequenced to further subtype $\mathrm{HCV}$ strains and identify genotypes 1a/1b. Data were analyzed with the Blast program (http://blast.ncbi.nlm.nih.gov). The study was approved by the Ethics Committee of the Fondazione IRCCS Policlinico San Matteo (protocol no. 20080009620). Informed consent was obtained from all subjects prior to enrollment.

Viral RNA was extracted from serum samples using the automatic Easy Mag extractor (Biomerieux, Lyon, France), and full-length $\mathrm{HCV}$ NS3/4A sequences were amplified using a nested RT-PCR. In detail, the primers used respectively in PCR and nested PCR, spanning NS3/4A aa from 1 to 181, were as follows: 1a-Forward outer $5^{\prime}$-GACATCATCAACGGCTTGCCCG-3' and 1aReverse outer 5'-GAGTACGTGATGGGGCTGCCAG-3', 1a-Forward inner 5'-GGAATGGTCTCCAAGGGGTG GA- $3^{\prime}$ and 1a-Reverse inner 5'-CATGGGCCTTGGA CATGTAAGC-3' for genotype 1a; 1b-Forward outer $5^{\prime}$ CGAGACCTTGCGGTGGCAGT-3' ${ }^{\prime}$ and 1b-Reverse outer 5'-CAGCCGTYTCCGCTTGGTCC-3', 1b-Forward inner 5'-CATCACCTGGGGGGCAGACACC-3' and 1b-Reverse inner $\quad 5^{\prime}$-GTCAGTTGAGTGGCACTCATCAC-3' for genotype 1b; 2abc-Forward outer 5'-GGCACHTAYATC TATGACCA-3' and 2-Reverse outer 5'-CAGYCCRATG GAGARGAARGTCA-3', 2-Forward inner 5'-GTYCTRA TGTTGGGRTTGATBCC-3' and 2-Reverse inner $5^{\prime}$ TASGCCCCAAAMCCMAGSGTGG-3' for genotype 2; 3 Forward outer $5^{\prime}$-GTCTCTGCRCGATTAGGCCGTGA-3' and 3-Reverse outer $5^{\prime}$-CAGTTTRGCACCAGTTGTAA CG-3', 3-Forward inner 5'-GTTGGGACCTGCTGATG ACTA-3' and 3-Reverse inner 5'-CCCAGTGCGGAT GTTGGGGT-3' for genotype 3; finally, 4-Forward outer $5^{\prime}$-GGGYAATGARATMYTGCTCGG-3' and 4-Reverse outer 5'-GCCAGGAACTTMCCRTABGT-3', 4-Forward inner 5'-GGAGRCTBCTYGCBCCCAT-3' and 4-Reverse inner $5^{\prime}$-GAGTAYGTGATYGGCGC-3' for genotype 4. The PCR products in the first round were obtained by using the following conditions: $15^{\prime}$ at $45^{\circ} \mathrm{C}$ for the reverse transcription followed by $10^{\prime}$ at $94^{\circ} \mathrm{C}$, and then 50 cycles at $94^{\circ} \mathrm{C}$ for $1,55^{\circ} \mathrm{C}$ for $1^{\prime}$ and $72^{\circ} \mathrm{C}$ for $70^{\prime \prime}$, with an extension at $72^{\circ} \mathrm{C}$ for $10^{\prime}$. Three microliters from the first PCR reaction were used in the nested PCR with the following conditions: denaturation step at $94^{\circ} \mathrm{C}$ for $10^{\prime}$ and then 30 cycles at $94^{\circ} \mathrm{C}$ for $1,52^{\circ} \mathrm{C}$ for $1^{\prime}$ and $72^{\circ} \mathrm{C}$ for $70^{\prime \prime}$, with an extension at $72^{\circ} \mathrm{C}$ for $10^{\prime}$.

Direct sequencing of PCR products was performed using an automatic sequencer (ABI PRISM 3100 genetic analyzer DNA Sequencer, Applied Biosystems, Foster City, CA, USA) and the BigDye Terminator v1.1 Cycle Sequencing kit (Applied Biosystems, Foster City, CA, USA).

Only variants present in more than $5 \%$ of the patient virus populations for each $\mathrm{HCV}$ genotype group were considered in the genotypic resistance analysis [12].

Nucleotide sequences were assembled using the Sequencer 4.6 (Gene Codes Corp., Ann Arbor, MI) software program. To obtain a detailed subtyping of $\mathrm{HCV}$ strains, nucleotide sequences were aligned with confirmed references of different subtypes using the ClustalW method which is embedded in the Mega 5 package [20].

The phylogeny of the sequences was constructed using the Neighbour Joining method. The nucleotide substitution model was selected according to Akaike Information Criterion scores. A Neighbour Joining tree was constructed with MEGA 5 software [20] setting the Tamura 3-parameter as an evolutionary model with an heterogeneous rate among sites using gamma distribution for the relative rate. Branch support was assessed by bootstrap analysis with 1000 replicates. Bootstrap values of $70 \%$ were used as the cut off point for cluster analysis. The sequences reported in this study have been submitted to the GenBank database under accession numbers $\mathrm{J} \times 170910$ to $\mathrm{J} \times 171065$.

The GenBank accession numbers for reference sequences used to determine the $\mathrm{HCV}$ genotypes were as follows: M62321 (subtype 1a), NC004102 (subtype 1a; H77-US1977), D90208 (subtype 1b), D14853 (subtype 1c), D00944 (subtype 2a), D10988 (subtype 2b), D50409 (subtype 2c), AB031663 (subtype $2 \mathrm{k}$ ), D17763 (subtype 3a), D49374 (subtype 3b), D63821 (subtype 3 k), Y11604 (subtype 4a), GU085486 (subtype 4a), FJ025855 (subtype 4b), FJ025854 (subtype 4b), FJ462436 (subtype 4c) FJ462437 (subtype 4d), EU392172 (subtype 4d), EU392170 (subtype 4f), FJ462432 (subtype $4 \mathrm{~g}$ ), FJ462438 (subtype $4 \mathrm{k}$ ), EU392171 (subtype 4 k) EU392173 (subtype 4 k), FJ839870 (subtype 4 l), FJ462433 (subtype $4 \mathrm{~m}$ ), FJ462441 (subtype 4n), FJ462440 (subtype 4o), FJ462431 (subtype 4p), FJ462434 (subtype 4q) FJ462439 (subtype 4r) FJ839869 (subtype 4 t), Y13184 (subtype 5a), Y12083 (subtype 6a), D84262 (subtype 6b), D84263 (subtype 6d), D63822 (subtype 6 g), D84265 (subtype 6 h), D84264 (subtype 6 k). 


\section{Results}

The clinical and virologic characteristics of patients considered in the study are provided in Table 1 . Fifteen patients (9.5\%) were co-infected with HIV and treated with highly active antiretroviral therapy (HAART) (Table 1).

Aa substitutions associated with HCV PI resistance were found in 50/156 (32\%) sequences of PI naïve HCV patients (Table 2). Mutations V36L, T54S, V55A/I, and Q80K/L were observed in 29\% of patients with genotype 1a, and V55F, Q80L/N and M175L in 10\% of patients with genotype $1 \mathrm{~b}$. Mutation V158M was found in $3 \%$ patients with genotype 2, D168Q was present in 100\% pts with genotype 3 and D168E was observed in 13\% of patients with genotype 4 (Table 2). In addition, multiple aa polymorphisms not associated with PI resistance were detected in all genotypes (Table 2).

Amino acids at positions S138 and V170 reported to be correlated with PI resistance when there is a change from $\mathrm{T}$ to T/A [7], respectively, changed to S138C and V170I in patients with genotype $1 \mathrm{~b}$ were not associated with PI resistance. In addition, all sequences of genotypes 2, 3 and 4 showed the mutation V36L which has been associated with PI resistance in HCV patients with genotype 1. Of note, HCV PI resistance mutations in $\mathrm{HCV} / \mathrm{HIV}$ co-infected patients were found in only one patient (Q80L).

A mutation at position 176 (S176N) different from that previously correlated with resistance (S176G) [11] was found in four patients with genotype 3. Previously reported [10] compensatory aa changes (I71V, I72T/F, and Q86P) were observed in both genotypes 1a and $1 \mathrm{~b}$. In individual genotype $1 \mathrm{~b}$ strains, the resistance mutation V55F was associated with compensatory mutation T72I, mutation Q80L/N was associated with Q86P and mutation M175L was associated with T72I and Q86P. In contrast, the two compensatory mutations in genotype 1a were detected in the absence of resistance mutations.
Finally, a number of polymorphisms not associated with PI resistance, were detected between codon 4 and codon 179 in all genotypes (Table 3 ). In genotypes $1 \mathrm{a}, 1 \mathrm{~b}$ and 4 multiple polymorphisms (4, 15 and 29 , respectively) were detected, while 11 and 17 polymorphisms were found in genotypes 2 and 3, respectively. In detail, the number of aa changes for each natural polymorphic site in the different genotypes was 104 in genotype 1a, 186 in genotype 1b, 84 in genotype 2, 97 in genotype 3 and 255 in genotype 4.

The mean genetic diversity of NS3 was higher in genotype $4(16.6 \%)$ than in genotype $1 \mathrm{~b}(12.0 \%), 1 \mathrm{a}(10.4 \%), 2$ $(11.2 \%)$, and $3(9.2 \%)$. Among patients infected with $\mathrm{HCV}$ genotype 1 , sequences were equally distributed in HCV subtypes $1 \mathrm{a}$ and $1 \mathrm{~b}$. The number of sequences carrying mutations associated with PI resistance was 2-fold higher in subtype 1a with respect to subtype $1 \mathrm{~b}(\mathrm{p}=$ 0.07) (Figure 1). All sequences clustering within genotype 2 , belonged to subtype $2 \mathrm{c}$ and only one sequence carried a mutation correlated with resistance. All sequences from patients infected with genotype 3 clustered in the subtype $3 \mathrm{a}$, and all sequences showed the D168Q change (Figure 1). Among the HCV genotype 4 sequences, 14/23 (60.9\%) belonged to subtype $4 \mathrm{~d}$, while, $6 / 23(26.1 \%)$ were subtype $4 a, 1 / 23(4.3 \%)$ was subtype $4 \mathrm{c}$ and $2 / 23$ (8.7\%) clustered together with an uncommon subtype (Figure 1). Among these, one sequence exhibited $91.6 \%$ identity with $\mathrm{HCV}$ subtype $4 \mathrm{~m}$, and the second exhibited $89.1 \%$ identity with $\mathrm{HCV}$ subtype $4 \mathrm{t}$ (bootstrap value $>99 \%$ ) (Figure 1).

All $\mathrm{HCV} / \mathrm{HIV}$ co-infected patients with genotype 4 clustered in the subtype 4c, while the mutations correlated with PI resistance were observed both in subtype 4c and subtype 4a (Figure 1). In particular, a mutation associated with PI resistance (D168E) was observed in two identical sequences (4-6706 $\mathrm{m} 11$ and 4-5208 m11) from different patients.

Table 1 Patient characteristics by HCV genotype

\begin{tabular}{|c|c|c|c|c|c|}
\hline \multirow[t]{2}{*}{ Characteristic } & \multicolumn{5}{|c|}{ HCV genotype } \\
\hline & $1 a(n=31)$ & $1 b(n=39)$ & $2(n=30)$ & $3(n=33)$ & $4(n=23)$ \\
\hline \multicolumn{6}{|l|}{ Gender } \\
\hline Male & $26(83 \%)$ & $20(51 \%)$ & $11(36 \%)$ & $26(78 \%)$ & 17 (85\%) \\
\hline Female & $5(27 \%)$ & 19 (49\%) & 19 (64\%) & 7 (22\%) & $3(15 \%)$ \\
\hline \multicolumn{6}{|l|}{ Race } \\
\hline Italian & $29(93 \%)$ & $38(97 \%)$ & $30(100 \%)$ & 31 (93\%) & $13(65 \%)$ \\
\hline Others & $2(7 \%)$ & $1(3 \%)$ & 0 & $2(7 \%)$ & $7(35 \%)$ \\
\hline $\begin{array}{l}\text { No. of patients HIV-1 co-infected } \\
\text { receiving HAART (\%) }\end{array}$ & 5 & 1 & 0 & 4 & 4 \\
\hline $\begin{array}{l}\left.\text { Median HCV viral load (IU/mL } \log _{10}\right) \\
\text { in HCV mono-infected pts }\end{array}$ & 5.66 (range 3.03-6.44) & 5.63 (range 4.2-6.75) & 5.96 (range 3.6-6.84) & 5.38 (range 2.97-6.58) & 5.66 (range 2.40-6.78) \\
\hline $\begin{array}{l}\left.\text { Median HCV viral load (IU/mL } \log _{10}\right) \\
\text { in HCV/HIV co-infected pts }\end{array}$ & 6.41 (range 4.73-6.77) & 5.95 & 0 & 6.54 (range 6.17-6.86) & 6.45 (range 6.42-6.52) \\
\hline
\end{tabular}


Table 2 Amino acid variations in the HCV NS3 protein associated with resistance mutations to HCV NS3 protease inhibitors, compensatory and enhanced replication

\begin{tabular}{|c|c|c|c|c|c|}
\hline \multirow{3}{*}{$\begin{array}{c}\text { NS3 } \\
\text { Protease } \\
\text { position }^{\text {a }}\end{array}$} & \multicolumn{5}{|c|}{ HCV variation in different genotypes (number of sequenced patients) } \\
\hline & $1 \mathrm{a}$ & $1 \mathrm{~b}$ & 2 & 3 & 4 \\
\hline & $(n=31)$ & $(n=39)$ & $(n=30)$ & $(n=33)$ & $(n=23)$ \\
\hline 36 (R) & V36L ${ }^{c}(2)^{e}$ & V36 & L36 & L36 & L36 \\
\hline $41(\mathrm{R})$ & Q41 & Q41 & Q41 & Q41 & Q41 \\
\hline $43(\mathrm{R})$ & F43 & F43 & F43 & $\mathrm{F} 43$ & $\mathrm{~F} 43$ \\
\hline $54(\mathrm{R})$ & $\operatorname{T54S}(2){ }^{e}$ & T54 & T54 & T54 & T54 \\
\hline $55(\mathrm{R})$ & V55A/I (2) ${ }^{\mathrm{e}}$ & V55F (1) ${ }^{\mathrm{e}}$ & V55 & V55 & V55 \\
\hline 79 (R) & D79 & D79 & E79 & D79 & D79 \\
\hline $80(\mathrm{R})$ & Q80K/L (3) ${ }^{\mathrm{e}}$ & Q80L/N (2) ${ }^{e}$ & G80 & Q80 & Q80 \\
\hline $109(R)$ & R109 & R109 & R109 & R109 & R109 \\
\hline $138(R)$ & S138 & $\mathrm{S} 138 \mathrm{C}(1)^{\mathrm{d}}$ & S138 & S138 & S138 \\
\hline $155(\mathrm{R})$ & R155 & R155 & R155 & R155 & R155 \\
\hline $156(R)$ & A156 & A156 & A156 & A156 & A156 \\
\hline $158(R)$ & V158 & V158 & $\operatorname{V158M}(1)^{e}$ & V158 & V158 \\
\hline $168(R)$ & D168 & D168 & D168 & D168Q (33) & D168E (3) \\
\hline $170(\mathrm{R})$ & 1170 & V170I (12) & 1170 & $1170 \mathrm{~V}(1)^{\mathrm{d}}$ & V170 \\
\hline $175(R)$ & L175 & M175L (1) ${ }^{e}$ & L175 & L175 & L175 \\
\hline $176(R)$ & E176 & E176 & D176 & S176N (4) ${ }^{d}$ & E176 \\
\hline $71(\mathrm{C})$ & V71 & $171 V / L(5)^{e}$ & V71 & A71S $(1)^{d}$ & V71 \\
\hline $72(C)$ & $172 T / F(2)^{e}$ & T72I/A/L (11) ${ }^{\mathrm{e}}$ & T72 & $\operatorname{L} 72 \mathrm{~F}(1)^{d}$ & $N 72 C(2)^{d}$ \\
\hline $86(C)$ & P86 & $\mathrm{Q86P}(6)^{\mathrm{e}}$ & P86S (1) & P86S (2) ${ }^{d}$ & P86 \\
\hline $88(C)$ & P88 & P88 & P88 & P88 & P88 \\
\hline
\end{tabular}

${ }^{a} \mathrm{R}$, position associated with primary resistance; C, position associated with compensatory mutations; (Lopez, 2008; Flint, 2009; Susser, 2009; Lentz, 2010; Verbimen, 2010; Romano, 2010, Halfon, 2011).

${ }^{b}$ Reference strains for each genotype: M62321 (1a), D90208 (1b), D50409 (2c), D17763 (3a), and Y11604 (4a).

'Letter on the left represents the wild type amino acid, on the right, the amino acid substitution. The number of patients with mutant HCV strains is indicated in brackets.

dPolymorphism with no associated resistance.

e Amino acid changes conferring resistance are reported in bold.

\section{Discussion}

The identification of baseline resistance mutations to anti-HCV PIs is crucial for defining new therapeutic approaches. Natural polymorphisms in the HCV NS3/ 4A protease-coding region were analyzed in 156 patients including genotypes 1a, 1b, 2, 3, and 4. Relevant natural aa polymorphisms were found among the different genotypes and subtypes. The data presented are important not only to determine whether PI-resistant mutants are likely to be present in PI treatment-naïve patients, but also for the examination of HCV protease among different genotypes and the possibility of eventually extending the PI treatment to non-genotype 1-infected patients. On the other hand, the study of preexisting viral variants to predict response to PIs for genotypes other than 1 might be misleading, since the molecular target structure could be considerably different between genotype 1 $\mathrm{HCV}$ and other genotypes. In fact, all recent clinical trials have been designed for treatment of $\mathrm{HCV}$ infections with genotype 1 [5,6,21]. Although culture systems for determining HCV susceptibility to PI compounds have been recently developed [4], the comparative genetic analysis of HCV strains in PI naïve patients infected with different virus genotypes may provide information useful for predicting treatment efficacy since, naturally occurring genotype-specific variations appear to have an effect in different HCV genotypes [22,23]. In addition, even though resistant viral variants exist at low frequency in untreated patients, specific NS3 protease mutations may have an important role in modulating resistance development and modifying viral fitness [22].

Substitutions at positions R155 and A156, which are known to confer a high level of resistance to all PIs [7,9], were not observed in our patients. In contrast, other minor mutations conferring low levels of resistance to PIs $[7,9,14,22]$ were found in $32 \%$ of patients. In addition, all sequences from genotypes 2,3 and 4 showed the V36L mutation which is known to confer 
Table 3 Amino acid variations in the HCV NS3 protein not associated with resistance mutations to HCV NS3 protease

\begin{tabular}{|c|c|c|c|c|c|c|c|c|c|c|c|}
\hline \multirow{2}{*}{$\begin{array}{l}\text { NS3 } \\
\text { Protease } \\
\text { position }^{\text {a }}\end{array}$} & \multicolumn{5}{|c|}{$\begin{array}{l}\text { HCV variation in different genotypes (number of } \\
\text { sequenced patients) }\end{array}$} & \multirow{2}{*}{$\begin{array}{c}\text { NS3 } \\
\text { Protease } \\
\text { position }^{\text {a }}\end{array}$} & \multicolumn{5}{|c|}{$\begin{array}{l}\text { HCV variation in different genotypes (number of sequenced } \\
\text { patients) }\end{array}$} \\
\hline & $\begin{array}{c}1 a \\
(n=31)\end{array}$ & $\begin{array}{c}1 b \\
(n=39)\end{array}$ & $\begin{array}{c}2 \\
(n=30)\end{array}$ & $\begin{array}{c}3 \\
(n=33)\end{array}$ & $\begin{array}{c}4 \\
(n=23)\end{array}$ & & $\begin{array}{c}1 a \\
(n=31)\end{array}$ & $\begin{array}{c}1 \mathrm{~b} \\
(\mathrm{n}=39)\end{array}$ & $\begin{array}{c}2 \\
(n=30)\end{array}$ & $\begin{array}{c}3 \\
(n=33)\end{array}$ & $\begin{array}{c}4 \\
(n=23)\end{array}$ \\
\hline 4 & & & & & T4P (14) & 67 & S67P/A (14) & & & $\mathrm{A} 67 \mathrm{~V} / \mathrm{T}(7)$ & \\
\hline 5 & & & & A5T/P (3) & A5G/C(6) & 69 & & & & H69R (2) & \\
\hline 7 & & S7A (12) & $\begin{array}{c}\text { A7TN } \\
(11)\end{array}$ & A7T(2) & & 72 & $172 \mathrm{~T} / \mathrm{F}(2)$ & $\begin{array}{c}\mathrm{T} 72 \mathrm{~A} / \mathrm{I} / \mathrm{L} \\
(13)\end{array}$ & & & \\
\hline 10 & & & & & $\mathrm{~T} 10 \mathrm{H} / \mathrm{N}(2)$ & 82 & & L82G (3) & & & \\
\hline 11 & & & & & R11P (2) & 83 & & V83N/T/I & & & \\
\hline 12 & & & & & G12A/R (3) & 91 & $\mathrm{~S} 91 \mathrm{~A} / \mathrm{T}(28)$ & A91S (5) & & A91T (4) & \\
\hline 13 & & & & & $\begin{array}{l}\mathrm{L} 13 \mathrm{M} / \mathrm{W} / \mathrm{T} \\
\quad(13)\end{array}$ & 92 & & T95E/S (2) & & & R92K/T (15) \\
\hline 14 & & L14F (5) & & L14F (3) & F14L/I (15) & 95 & & & & E95D (3) & A95T/S (4) \\
\hline 15 & & & $\begin{array}{l}\mathrm{D} 15 \mathrm{G} \\
(28)\end{array}$ & & S15G (12) & 98 & & & & A/98 T (15) & \\
\hline 16 & & & A16T (8) & & & 101 & & & & & S101A (8) \\
\hline 18 & I18V (2) & I18V (4) & & & V18I (3) & 102 & & & & S102A (3) & A102S (20) \\
\hline 20 & & & & S20G (4) & & 105 & & & & & Y105F (14) \\
\hline 24 & & & & R24K (2) & R24K (3) & 107 & & V107I (4) & & & \\
\hline 26 & & K26R (3) & & & & 110 & & & & D110E (5) & H110N (3) \\
\hline 28 & $\begin{array}{l}\text { Q28E/L } \\
(3)\end{array}$ & & D28E (2) & $\begin{array}{l}\mathrm{V} 281 / \mathrm{M} \\
(5)\end{array}$ & & 114 & I114V (3) & V114I (26) & & & I114V (18) \\
\hline 33 & V33I (2) & & V33I (10) & & V33I (13) & 117 & & $\mathrm{R} 117 \mathrm{H} / \mathrm{C}(4)$ & & & \\
\hline 35 & & V35I (5) & V35I (3) & & & 119 & & & $\begin{array}{l}\mathrm{R} 119 \mathrm{Q} \\
(2)\end{array}$ & & \\
\hline 39 & & A39T (3) & & & & 122 & S122G (10) & $\mathrm{S} 122 \mathrm{~T} / \mathrm{C}$ (5) & & & T122S (2) \\
\hline 40 & $\begin{array}{l}\mathrm{A} 40 \mathrm{~T} / \mathrm{S} \\
(9)\end{array}$ & & & & & 123 & & R123K (3) & & & \\
\hline 42 & & S42T/F (5) & & & & 127 & & & & & L127I (11) \\
\hline 44 & & & & & L44M (2) & 132 & & $\begin{array}{l}\text { I132V/M } \\
(18)\end{array}$ & & L132I (2) & \\
\hline 46 & & T46S/A (2) & & & & 134 & & & $\begin{array}{l}\text { S134T } \\
(13)\end{array}$ & & \\
\hline 47 & & & & & $\mathrm{~A} 47 \mathrm{G} / \mathrm{S}(2)$ & 146 & & & P146S (2) & & \\
\hline 48 & $148 \mathrm{~V}(4)$ & V48I/L (14) & & & V48I (11) & 147 & & S147L (2) & & $\begin{array}{l}\text { S147L/A/R/T } \\
\text { (5) }\end{array}$ & $\begin{array}{l}\text { M147L/Q } \\
(15)\end{array}$ \\
\hline 49 & & N49S (2) & & & & 150 & & V150A (29) & & & R150V/A (20) \\
\hline 51 & & V51A (2) & $\begin{array}{l}\mathrm{V} 51 \mathrm{~T} / \mathrm{A} \\
(3)\end{array}$ & & & 151 & & & & & A151V (3) \\
\hline 56 & & Y56F/C (4) & & & & 153 & & I153V/L (3) & & & \\
\hline 60 & & $\begin{array}{c}\text { S60AT/P } \\
(7)\end{array}$ & & & & 166 & & & & S166A/T (3) & \\
\hline 61 & T61S (2) & K61R (4) & & & & 174 & $\begin{array}{c}\mathrm{N} 174 \mathrm{~S} / \mathrm{G} \\
(23)\end{array}$ & S174A/L (3) & $\mathrm{S} 174 \mathrm{~T}(2)$ & & \\
\hline 64 & 164L (2) & & & & & 177 & & & V177I (3) & & \\
\hline 65 & & & & & S65C (2) & 179 & & & & A179TN (2) & \\
\hline
\end{tabular}

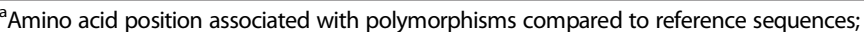

${ }^{b}$ Reference strain accession numbers for each genotype: M62321 (1a), D90208 (1b), D50409 (2c), D17763 (3a), and Y11604 (4a).

'Letter on the left represents the wild type amino acid, on the right, the amino acid substitution. The number of patients with mutant HCV strains is indicated in brackets. 


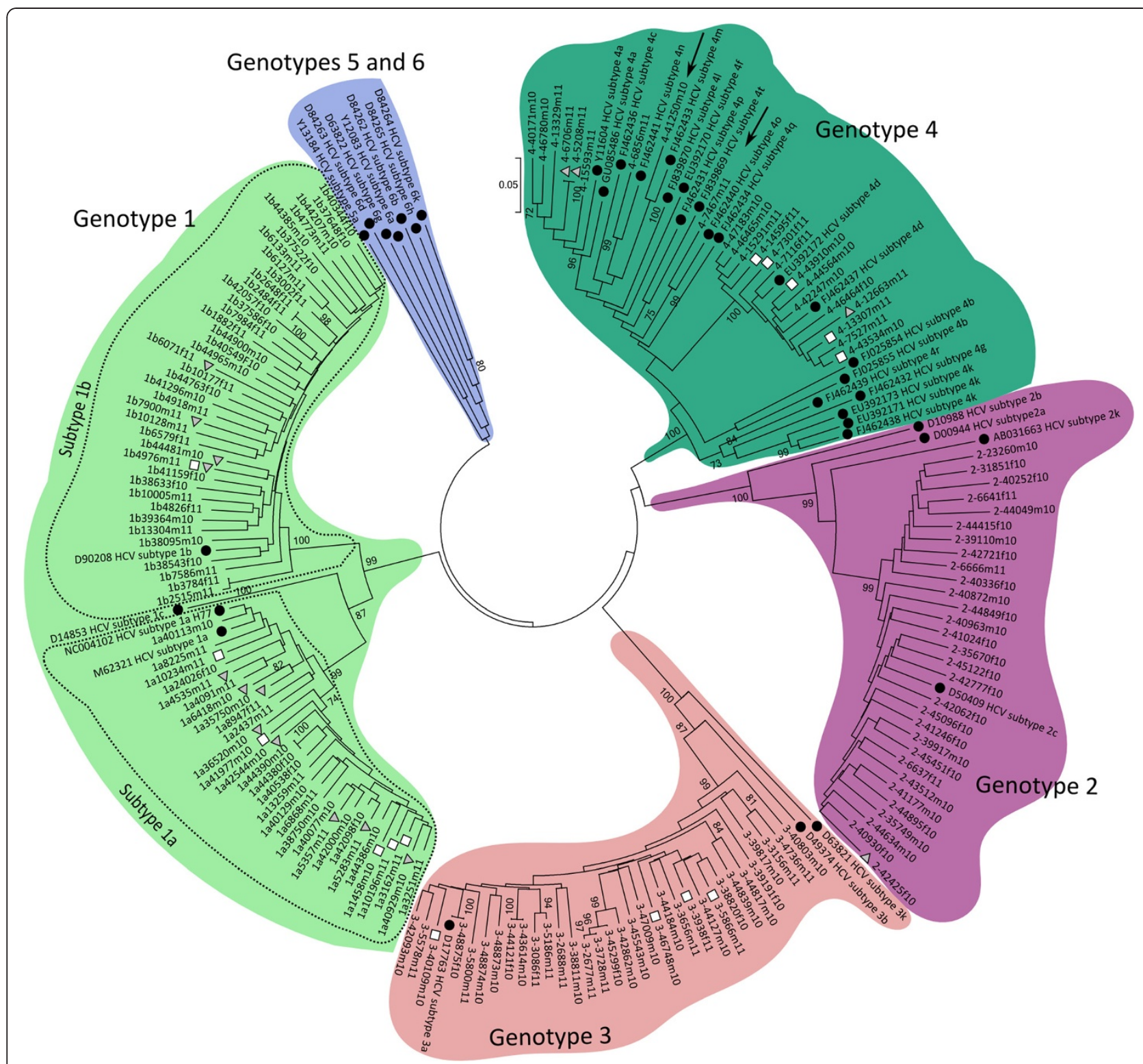

Figure 1 Phylogenetic analysis of HCV protease in PI-naïve patients. Black circles $\bullet$ indicate available reference sequences; grey triangles protease baseline resistant patients; white squares $\square$, HIV co-infected patients.

decreased susceptibility to telaprevir $[7,24]$ and all sequences from genotype 3 showed the D168Q mutation which is known to decrease the activity of non-covalent HCV NS3 protease inhibitors against genotype $3(4,14)$. Moreover, a higher number of polymorphic sites in $\mathrm{HCV}$ protease NS3/4A were observed in genotypes $1 \mathrm{~b}$ and 4 compared with genotypes $1 \mathrm{a}, 2$ and 3 . Further studies are needed to better understand the potential implications on treatment of PI naïve patients with resistance at baseline which could influence the treatment failure rate. On the other hand the clinical role of compensatory mutations impacting the viral fitness of PI resistant strains [25-27] requires additional investigation.
In contrast with reported observations [28], HCV PI resistance mutations were not observed more frequently in $\mathrm{HCV} / \mathrm{HIV}$ co-infected patients than $\mathrm{HCV}$ monoinfected patients. Phylogenetic analysis confirmed the greater heterogeneity of $\mathrm{HCV}$ genotypes $1 \mathrm{~b}$ and 4 , which may be explained by the presence of several divergent sequences with respect to other genotypes. In keeping with data from the Italian $\mathrm{HCV}$ genotype distribution [29], subtype $4 \mathrm{~d}$ strains were observed also in our series. In this data set, a wide distribution of mutations correlating with PI resistance was observed in all genotypes. A larger data set of $\mathrm{HCV}$ sequences including baseline data would clarify this finding. 
In conclusion, i) the natural variability in all $\mathrm{HCV}$ viral populations (HIV co-infected or mono-infected) observed in our study confirms [30-32] and underlines their potential implication in the management of $\mathrm{HCV}$ treatment; ii) no major mutations associated with resistance to PIs were observed in HCV PI naïve patients, on the contrary, a consistent number of minor mutations which may reduce the efficacy of PIs were detected in genotypes $1 \mathrm{a}, 1 \mathrm{~b}$ and also in genotypes 2,3 and 4 . Thus, the inclusion of patients with different genotypes in future larger clinical trials, would help define the efficacy of anti HCV PIs in patients infected with different genotypes and these data could be extended to design treatment protocols. In addition, further investigations are necessary to understand the utility of resistance analysis at baseline to evaluate response to $\mathrm{HCV}$ protease inhibitors.

\section{Consent}

Written informed consent was obtained from patients for publication of this manuscript and any accompanying images. A copy of the letter of consent is available for review by the Editor-in-Chief of this journal.

\section{Competing interests}

The authors declare that they have no financial or competing interests.

\section{Authors' contributions}

SP study design, data analysis and paper writing. LF, AP, MG, LD sequencing and phylogenetic analysis. RG, SN, GB, PS patient enrolment. FB data analysis, manuscript revision and fund raising. All authors read and approved the final manuscript.

\section{Acknowledgements}

The authors thank Daniela Sartori for manuscript editing and Laurene Kelly for revision of the English. The work was supported by the Ministero della Salute, Ricerca Corrente grant no. 80207.

\section{Author details}

${ }^{1}$ Molecular Virology Unit, Virology and Microbiology Department, Fondazione IRCCS Policlinico San Matteo, Pavia 27100, Italy. ${ }^{2}$ Institute of Infectious Diseases, University of Pavia, Pavia 27100, Italy. ${ }^{3}$ Division of Infectious and Tropical Diseases, Fondazione IRCCS Policlinico San Matteo, Pavia 27100, Italy.

Received: 17 February 2012 Accepted: 18 October 2012

Published: 24 October 2012

\section{References}

1. Lauer GM, Walker BD: Hepatitis C virus infection. N Engl J Med 2001, 345:41-52.

2. Manns MP, McHutchison JG, Gordon SC, Rustgi VK, Shiffman M, Reindollar R, Goodman ZD, Koury K, Ling M, Albrecht JK: Peginterferon alfa-2b plus ribavirin compared with interferon alfa- $2 b$ plus ribavirin for initial treatment of chronic hepatitis C: a randomised trial. Lancet 2001, 358:958-965.

3. Hadziyannis SJ, Sette H Jr, Morgan TR, Balan V, Diago M, Marcellin P, Ramadori G, Bodenheimer H Jr, Bernstein D, Rizzetto M, Zeuzem S, Pockros PJ, Lin A, Ackrill AM, PEGASYS International Study Group: Peginterferonalpha2a and ribavirin combination therapy in chronic hepatitis C: a randomized study of treatment duration and ribavirin dose. Ann Intern Med 2004, 140:346-355.

4. Gottwein JM, Scheel TK, Jensen TB, Ghanem L, Bukh J: Differential efficacy of protease inhibitors against HCV genotypes $2 a, 3 a, 5 a$ and $6 a$ NS3/4A protease recombinant viruses. Gastroenterology 2011, 141:1067-1079.
5. Sarrazin C, Kieffer TL, Bartels D, Hanzelka B, Müh U, Welker M, Wincheringer D, Zhou Y, Chu HM, Lin C, Weegink C, Reesink H, Zeuzem S, Kwong AD: Dynamic hepatitis $C$ virus genotypic and phenotypic changes in patients treated with the protease inhibitor telaprevir. Gastroenterology 2007, 132:1767-1777.

6. Kieffer TL, Sarrazin C, Miller JS, Welker MW, Forestier N, Reesink HW, Kwong $A D$, Zeuzem S: Telaprevir and pegylated interferon-alpha-2a inhibit wildtype and resistant genotype 1 hepatitis $C$ virus replication in patients. Hepatology 2007, 46:631-639.

7. Lenz $\mathrm{O}$, Verbinnen $\mathrm{T}$, Lin TI, Vijgen L, Cummings MD, Lindberg J, Berke JM, Dehertogh $\mathrm{P}$, Fransen $\mathrm{E}$, Scholliers A, Vermeiren $\mathrm{K}$, Ivens T, Raboisson $\mathrm{P}$, Edlund $M$, Storm S, Vrang L, de Kock H, Fanning GC, Simmen KA: In vitro resistance profile of the hepatitis $C$ virus NS3/4A protease inhibitor TMC435. Antimicrob Agents Chemother 2010, 54:1878-1887.

8. Romano KP, Ali A, Royer WE, Schiffer CA: Drug resistance against HCV NS3/4A inhibitors is defined by the balance of substrate recognition versus inhibitor binding. PNAS 2010, 107:20986-20991.

9. Halfon P, Locarnini S: Hepatitis C virus resistance to protease inhibitors. J Hepatol 2011, 55:192-206.

10. López-Labrador FX, Moya A, Gonzàlez-Candelas F: Mapping natural polymorphisms of hepatitis C virus NS3/4A protease and antiviral resistance to inhibitors in worldwide isolates. Antivir Therapy 2008, 13:481-494.

11. Flint M, Mullen S, Deatly AM, Chen W, Miller LZ, Ralston R, Broom C, Emini EA, Howe AY: Selection and characterization of hepatitis $C$ virus replicons dually resistant to the polymerase and protease inhibitors HCV-796 and boceprevir (SCH503034). Antimicrob Agents Chemother 2009, 53:401-411.

12. Susser $S$, Welsch $C$, Wang $Y$, Zettler M, Domingues FS, Karey U, Hughes E, Ralston R, Tong X, Herrmann E, Zeuzem S, Sarrazin C: Characterization of resistance to the protease inhibitor boceprevir in hepatitis $C$ virusinfected patients. Hepatology 2009, 50:1709-1718.

13. Verbinnen $T$, Van Marck H, Vandenbroucke I, Vijgen L, Claes M, Lin TI, Simmen K, Neyts J, Fanning G, Lenz O: Tracking the evolution of multiple in vitro hepatitis $C$ virus replicon variants under protease inhibitor selection pressure by 454 deep sequencing. J Virol 2010, 84:11124-11133.

14. Guo Z, Prongay A, Tong X, Fischmann T, Bogen S, Velazquez F, Venkatraman $S$, Njoroge FG, Madison V: Computational study of the effects of mutations A156T, D168V, and D168Q on the binding of HCV protease inhibitors. J Chem Theory Comput 2006, 2:1657-1663.

15. Thompson AJ, McHutchison JG: Antiviral resistance and specifically targeted therapy for HCV (STAT-C). J Viral Hepat 2009, 16:377-387.

16. Kuntzen T, Timm J, Berical A, Lennon N, Berlin AM, Young SK, Lee B, Heckerman D, Carlson J, Reyor LL, Kleyman M, McMahon CM, Birch C, Schulze Zur Wiesch J, Ledlie T, Koehrsen M, Kodira C, Roberts AD, Lauer GM, Rosen HR, Bihl F, Cerny A, Spengler U, Liu Z, Kim AY, Xing Y, Schneidewind A, Madey MA, Fleckenstein JF, Park VM, Galagan JE, Nusbaum C, Walker BD, Lake-Bakaar GV, Daar ES, Jacobson IM, Gomperts ED, Edlin BR, Donfield SM, Chung RT, Talal AH, Marion T, Birren BW, Henn MR, Allen TM: Naturally occurring dominant resistance mutations to hepatitis $C$ virus protease and polymerase inhibitors in treatment-naïve patients. Hepatology 2008, 48:1769-1778

17. Trimoulet $P$, Belzunce $C$, Faure M, Wittkop L, Reigadas S, Dupon M, Ragnaud JM, Fleury H, Neau D: Hepatitis C virus (HCV) protease variability and anti$\mathrm{HCV}$ protease inhibitor resistance in HIV/HCV-coinfected patients. HIV Med 2011, 12:506-509.

18. Halfon $P$, Bourlière $M$, Khiri $H$, Pénaranda $G$, Martineau $A$, Oulès $V$, Courcambeck J, Philibert P: Mutation rate in hepatitis C virus NS3 protease is not influenced by HIV-1 protease inhibitor therapy. AIDS 2008, 22:1694-1696.

19. Morsica G, Bagaglio S, Uberti-Foppa C, Galli L, Lazzarin A: Detection of hepatitis $C$ mutants with natural resistance to NS3/4A protease inhibitors in HIV/HCV-coinfected individuals treated with antiretroviral therapy. J Acquir Immune Defic Syndr 2009, 51:106-108.

20. Tamura K, Peterson D, Peterson N, Stecher G, Nei M, Kumar S: MEGA5: molecular evolutionary genetics analysis using maximumlikelihood, evolutionary distance, and maximum parsimony methods. Mol Biol Evol 2011, 28:2731-2739.

21. Pawlotsky JM: Treatment failure and resistance with direct-acting antiviral drugs against hepatitis C virus. Hepatology 2011, 53:1742-1751.

22. Welsch C, Schweizer S, Shimakami T, Domingues FS, Kim S, Lemon SM, Antes I: Ketoamide resistance and hepatitis $C$ virus fitness in val55 
variants of the NS3 serine protease. Antimicrob Agents Chemother 2012 56:1907-1915.

23. Thibeault D, Bousquet C, Gingras R, Lagacé L, Maurice R, White PW, Lamarre D: Sensitivity of NS3 serine proteases from hepatitis C virus genotypes 2 and 3 to the inhibitor BILN 2061. J Virol 2004, 78:7352-7359.

24. Zhou Y, Bartels DJ, Hanzelka BL, Müh U, Wei Y, Chu HM, Tigges AM, Brennan DL, Rao BG, Swenson L, Kwong AD, Lin C: Phenotypic characterization of resistant Val36 variants of hepatitis C virus NS3-4A serine protease. Antimicrob Agents Chemother 2008, 52:110-120.

25. Lin C, Luong YP, Rao BG, Wei YY, Brennan DL, Fulghum JR, Hsiao HM, Ma S, Maxwell JP, Cottrell KM, Perni RB, Gates CA, Kwong AD: In vitro resistance studies of hepatitis $C$ virus serine protease inhibitors, VX-950 and BILN 2061: structural analysis indicates different resistance mechanisms. J Biol Chem 2004, 279:17508-17514.

26. Yi M, Tong X, Skelton A, Chase R, Chen T, Prongay A, Bogen SL, Saksena AK, Njoroge FG, Veselenak RL, Pyles RB, Bourne N, Malcolm BA, Lemon SM: Mutations conferring resistance to $\mathrm{SCH} 6$, a novel hepatitis C virus NS3/ $4 \mathrm{~A}$ protease inhibitor. Reduced RNA replication fitness and partial rescue by second-site mutations. J Biol Chem 2006, 281:8205-8215.

27. Liu R, Abid K, Pichardo J, Pazienza V, Ingravallo P, Kong R, Agrawal S, Bogen S, Saksena A, Cheng KC, Prongay A, Njoroge FG, Baroudy BM, Negro F: In vitro antiviral activity of SCH446211 (SCH6), a novel inhibitor of the hepatitis $\mathrm{C}$ virus NS3 serine protease. J Antimicrob Chemother 2007, 59:51-58.

28. Eshun-Wilson I, Plas HV, Prozesky HW, Zeier MD, Nachega J, Taljaard Jj: Combined antiretroviral treatment initiation during hospitalization: outcomes in South African adults. JAIDS 2009, 51:106-108.

29. Argentini C, Dettori S, Villano U, Guadagnino V, Infantolino D, Dentico P, Coppola RC, Rapicetta M: Molecular characterization of HCV genotype 4 isolates circulating in Italy. J Med Virol 2000, 62:84-90.

30. Vallet S, Gouriou S, Nousbaum JB, Legrand-Quillien MC, Goudeau A, Picard B: Genetic heterogeneity of the NS3 protease gene in hepatitis $C$ virus genotype 1 from untreated infected patients. J Med Virol 2005, 75:528-537.

31. Winters MA, Welles $S L$, Holodniy M: Hepatitis C virus protease gene diversity in patients coinfected with human immunodeficiency virus. $J$ Virol 2006, 80:4196-4199.

32. Franco S, Parera M, Aparicio E, Clotet B, Martinez MA: Genetic and catalytic efficiency structure of an HCV protease quasispecies. Hepatology 2007, 45:899-910.

doi:10.1186/1743-422X-9-245

Cite this article as: Paolucci et al: Naturally occurring mutations to HCV protease inhibitors in treatment-naïve patients. Virology Journal 2012 9:245.

\section{Submit your next manuscript to BioMed Central and take full advantage of:}

- Convenient online submission

- Thorough peer review

- No space constraints or color figure charges

- Immediate publication on acceptance

- Inclusion in PubMed, CAS, Scopus and Google Scholar

- Research which is freely available for redistribution 